\title{
An Ethanol/Ether Soluble Apoprotein from Rat Lung Surfactant Augments Liposome Uptake by Isolated Granular Pneumocytes
}

\author{
William D. Claypool, Danny L. Wang, Avinash Chander, \\ and Aron B. Fisher \\ Department of Physiology, University of Pennsylvania School \\ of Medicine, Philadelphia, Pennsylvania 19104
}

bstract. Ethanol/ether soluble apoproteins, comprising $17 \%$ of the total recovered surfactant-associated proteins, were isolated from rat lung surfactant and purified by silicic acid chromatography. The protein that eluted in $4: 1$ chloroform/methanol accounted for $>85 \%$ of protein in the ethanol/ether soluble fraction and was termed surfactant apoprotein Et (Apo Et). By sodium dodecyl sulfate polyacrylamide gel electrophoresis, this protein had an apparent molecular weight of $\sim$ 10,500. Apo Et was evaluated for its effect on uptake of synthetic phospholipids in liposomal form by isolated granular pneumocytes (Type II alveolar epithelial cells) in primary culture. Liposomes were prepared to approximate the phospholipid composition of the aveolar surfactant, and uptake was measured by the accumulation of the radioactively labeled dipalmitoyl phosphatidyl choline fraction. The uptake of liposomal phosphatidylcholine by cells incubated for $2 \mathrm{~h}$ with Apo Et was increased by $61 \%$ over control. Most of the cell-associated phospholipid uptake was resistant to treatment with trypsin, suggesting an increased internalization of liposomal material in the presence of Apo Et. The effect of Apo Et on uptake was concentration and time dependent and was not associated with cell damage, phospholipase

This work was presented in part at the 65th Annual Meeting of the Federation of American Societies for Experimental Biology, April 1981, Atlanta, Georgia: the fall meeting of the American Physiological Society, October 1981, Cincinnati, Ohio; and the 77th Annual Meeting of the American Thoracic Society, May 1982, Los Angeles, California.

Dr. Claypool is currently with the Department of Medicine, University of Illinois School of Medicine.

Address reprint requests to Dr. Fisher.

Received for publication 14 March 1983 and in revised form 18 April 1984.

J. Clin. Invest.

(c) The American Society for Clinical Investigation, Inc.

0021-9738/84/09/0677/08 $\$ 1.00$

Volume 74, September 1984, 677-684 activity, or detergent properties of the protein. Apo Et had no significant effect on phosphtidylcholine uptake by granular pneumocytes maintained for $7 \mathrm{~d}$ in primary culture. Apo Et augmented the uptake of phospholipids by alveolar macrophages although total uptake by these cells was less than that observed with granular pneumocytes. Because Apo Et increases the rate of uptake of surfactant phospholipids by alveolar cells (granular pneumocytes and alveolar macrophages), this protein may represent a physiologically important regulator for clearance of lung surfactant phospholipids.

\section{Introduction}

The complex substance that lines the epithelial surface of the lung has been closely scrutinized in many laboratories over the last decade. It is now well accepted that the granular pneumocyte (Type II cell) secretes the surfactant material that permits the alveoli to maintain the expanded state necessary to sustain extrauterine life $(1,2)$. As has been emphasized in several recent reviews, the phospholipid components of this material are of paramount importance for its physiological role (3-5). On the other hand, the protein component of surfactant has been less extensively studied and an understanding of its physiologic role has been more elusive.

There is general agreement that the surfactant-associated protein comprises both serum protein and surfactant-specific apoproteins. The heterogenous surfactant specific apoproteins can be classified by their solubility in ethanol/ether. The major group of proteins is insoluble in ethanol/ether and has been studied extensively by King and associates (6). At least two proteins have been identified in this group. One (apoprotein A) has a molecular weight of 30,000 to 40,000 when assessed by sodium dodecyl sulfate (SDS)-polyacrylamide gel electrophoresis done under reducing conditions, whereas the second (apoprotein B) has a molecular weight of $\sim 10,000$. Although these proteins show partial immunoreactive identity, they can be differentiated by the kinetics of their secretion and removal from the alveolar space, their amino acid composition, and their solubility in organic solvents (7-10). Recently, Phizackerley and his collaborators have isolated ethanol/ether soluble pro- 
teins from the surfactant fraction of pig lung (11). These latter proteins accounted for $13 \%$ of the surfactant-associated protein from pig lung lavage and $40 \%$ of the total protein recovered from the lamellar body fractions of pig lung homogenates (11). Both the hydrophobic proteins of Phizackerly et al. and the apoprotein B of King appear to be closely associated with surfactant phospholipids.

Several recent studies $(12,13)$ have provided evidence that the phospholipids in the alveolar surfactant are recycled through the lung as part of normal surfactant turnover. To evaluate further this aspect of surfactant metabolism, we have used isolated granular pneumocytes in primary culture as a model for phospholipid recycling. These cells synthesize and secrete phospholipids and also show accumulation of exogenous liposomal phospholipids (14). The uptake of liposomes in this system appears to be accomplished by surface binding followed by the internalization of phospholipid vesicles through the mechanism of endocytosis and/or membrane fusion. This process provides a basis for the clearance of phospholipids from the alveolar space and the reuse of phospholipid substrate for surfactant synthesis.

The purpose of the present study was to evaluate the possibility that surfactant-associated proteins modulate the recycling of phospholipids in the alveolar space. Because Phizackerly et al. (11) had demonstrated that the ethanol/ether soluble proteins in the surfactant were strongly lipid associated and hydrophobic, we isolated this fraction and assessed its possible role in the uptake of phospholipids by granular pneumocytes.

\section{Methods}

Isolation of surfactant-associated proteins. To isolate the surfactant fraction from the lung lavage material, we used the method of Katyal et al. with minor modifications (15). Sprague-Dawley rats (Charles River Breeding Laboratories, Wilmington, MA) weighing 200-250 g were anesthetized with intraperitoneal pentobarbital $(50 \mathrm{mg} / \mathrm{kg}$ body $\mathrm{wt})$. The lungs from 10-21 rats were perfused free of blood with saline, excised en bloc, and lavaged with chilled saline. The lung washings were centrifuged at $350 \mathrm{~g}$ for $10 \mathrm{~min}$ to remove cellular debris. The supernatant was centrifuged at $20,000 \mathrm{~g}$ for $35 \mathrm{~min}$ to obtain the surfactant pellet. The pellet was resuspended as described by Katyal et al. (15) and applied to a discontinuous sodium bromide-sodium chloride gradient which was centrifuged at $65,000 \mathrm{~g}$ for $90 \mathrm{~min}$. The surfactant fraction was collected, diluted 1:10 with distilled water, and recentrifuged at $20,000 \mathrm{~g}$ for $35 \mathrm{~min}$. The resultant pellet was resuspended in water, dialyzed against $5 \mathrm{mM}$ EDTA for $24 \mathrm{~h}$ in a dialysis membrane with a pore exclusion limit of $3,500 \mathrm{~mol} \mathrm{wt}$ (Spectrapor Membrane; Spectrum Medical Industries, Inc., Los Angeles, CA), and then lyophilized to dryness.

The lyophilized surfactant powder was mixed with a solution of $1: 3 \mathrm{ethanol} / \mathrm{ether}(\mathrm{vol} / \mathrm{vol})$ at $4^{\circ} \mathrm{C}$ for $16 \mathrm{~h}$ with $1 \mathrm{ml}$ of organic solvent for every $1 \mathrm{mg}$ of surfactant-EDTA powder. After extraction, the ethanol/ether solution was centrifuged at $3,000 \mathrm{~g}$ for $10 \mathrm{~min}$ and the surfactant was filtered through No. 1 paper (Whatman Laboratory Products Inc., Whatman Paper Div., Clifton, NJ). The filtrate was saved on ice and the residue was re-extracted in 1:3 ethanol/ether (vol/ vol) at $4^{\circ} \mathrm{C}$ for $90 \mathrm{~min}$. The material was then refiltered as before and the residue was re-extracted with anhydrous ether. The ether/ethanol insoluble residue recovered after centrifugation was dried at room temperature and stored at $-20^{\circ} \mathrm{C}$. All filtrates representing the ethanol/ ether soluble material were combined, evaporated to dryness under $\mathrm{N}_{2}$, and dissolved in chloroform.

Proteins in the ethanol/ether soluble fraction were separated by silicic acid chromatography by means of a modification of the solvent system described by Phizackerley et al. (11). We used $3 \mathrm{mg}$ of activated silicic acid (Silicar CC7 Special; Mallinckrodt Inc., Science Products Div., St. Louis, MO) for every $10 \mathrm{mg}$ of phospholipid. The elution column was $0.6 \mathrm{~cm}$ in internal diameter and $17 \mathrm{~cm}$ in height. We used a constant solvent volume head of $20 \mathrm{~cm}$ throughout the elution. The elution was done by gravity with chloroform/methanol solvent mixtures (volume/volume) applied in the following order: $30 \mathrm{ml}$ chloroform; $30 \mathrm{ml}$ of $20: 1$ chloroform/methanol; $45 \mathrm{ml}$ of 9:1 chloroform/methanol; $30 \mathrm{ml}$ of $4: 1$ chloroform/methanol; $30 \mathrm{ml}$ of $3: 2$ chloroform/methanol; $30 \mathrm{ml}$ of 1:4 chloroform/methanol; and $30 \mathrm{ml}$ of 1:9 chloroform/methanol. Fractions $(1.5 \mathrm{ml}$ each) of the effluent from the column were collected for measurement of protein concentration and phospholipid phosphorous. Fractions from each solvent pool were combined, dried under $\mathrm{N}_{2}$, and stored in chloroform at $-20 \mathrm{C}$.

Cell isolation. Granular pneumocytes were isolated by trypsinization of minced rat lungs and differential adherence by the use of methods previously described (16). Preparations were $>90 \%$ granular pneumocytes with alveolar macrophages as the contaminating cell. Preparations of pure alveolar macrophages were obtained from rats by lung lavage (17). Cells were maintained in primary culture for $24 \mathrm{~h}$ before use and were studied while attached to the plastic culture plates. In some experiments, granular pneumocytes were maintained in culture for $7 \mathrm{~d}$ before study; medium was changed daily during this prolonged culture period. These latter cells were termed modified granular pneumocytes since the cells lose their characteristic lamellar inclusions during this culture period (18).

Preparation of liposomal phosphatidylcholine. Liposomes were made from a lipid mixture with molar ratio of 0.75 phosphatidylcholine $(\mathrm{PC})^{1}$ (2/3 dipalmitoyl phosphatidylcholine [DPPC] and $1 / 3 \mathrm{egg}$ PCs), 0.15 cholesterol, and 0.10 phosphatidylglycerol (all from Sigma Chemical Co., St. Louis, MO) to approximate the normal phospholipid composition of surfactant (2). ${ }^{3} \mathrm{H}$ - or ${ }^{14} \mathrm{C}$-labeled DPPC (New England Nuclear, Boston, MA) was added to the lipid solution before evaporation of the organic solvent to give a specific activity of $0.64 \mathrm{Ci} / \mathrm{mol} \mathrm{PC}$. Liposomes were made by vigorous mixing of the evaporated lipid film with $0.01 \mathrm{M} \mathrm{Na}$ phosphate-buffered saline, pH 7.4 (PBS). After the suspension was well mixed, the lipids were sonicated at $48^{\circ} \mathrm{C}$ with three 1-min bursts with a probe sonicator (Model 150; Artek Systems Corp., Farmingdale, NY) by means of $40 \%$ of maximum power output. The liposome suspension was stored at $4^{\circ} \mathrm{C}$ overnight and was centrifuged at $1,000 \mathrm{~g}$ to remove multilamellar liposomes or large aggregates before use (19).

The major ethanol/ether soluble protein that was eluted from the silicic acid column was incorporated into vesicles by the dissolving of lipids plus protein in chloroform followed by evaporation under $\mathbf{N}_{2}$. The dried residue was suspended in PBS and sonicated. In some experiments, the protein was added separately to the cells $5 \mathrm{~min}$ before the addition of the liposomes. For these latter experiments, the

1. Abbreviations used in this paper: Apo Et, apoprotein Et; DPPC, dipalmitoyl phosphatidylcholine; PC, phosphatidylcholine. 
chloroform which contained ethanol/ether soluble proteins was evaporated under $\mathrm{N}_{2}$ and the protein was then dispersed in culture media with a probe sonicator as described above. The proteins in the dried ethanol/ether insoluble fraction were suspended in PBS before they were added to cell cultures. In experiments where we evaluated the whole ethanol/ether soluble fraction before silicic acid chromatography, we evaporated this fraction under $\mathrm{N}_{2}$. The dried residue was then dissolved in chloroform and $\left[{ }^{3} \mathrm{H}\right] \mathrm{DPPC}$ was added as a tracer. Specific activity was calculated by use of the measured PC in this extract. The chloroform was then evaporated off under $\mathrm{N}_{2}$, and lipid vesicles were prepared as described above.

Cell uptake of liposomes. Cells were incubated at $37^{\circ} \mathrm{C}$ with liposomes (plus or minus proteins), usually at $21 \mu \mathrm{M}$ total PC concentration. At the end of incubation, granular pneumocytes were washed with liposome-free medium and then removed from plates by treatment with $0.25 \%$ trypsin for $10 \mathrm{~min}$. Alveolar macrophages were scraped with a rubber policeman. The cells were separated by centrifugation at $500 \mathrm{~g}$ for $10 \mathrm{~min}$, rewashed, and recentrifuged. The cell pellet was disrupted by probe sonication. The sonicated pellet was analyzed for protein and the pellet and pooled supernatants were analyzed for radioactivity. Cell-associated radioactivity was corrected for nonspecific absorption of liposomes to the plastic, which had been exposed to the primary cell culture medium in the absence of cells. This correction did not exceed $20 \%$ of total uptake and was not affected by the presence of surfactant-associated protein. Uptake was expressed in nanomoles of PC, based on the specific activity of total $\mathrm{PC}$ in the vesicles.

In some experiments, total radioactivity associated with cells after incubation was partitioned into trypsin-releasable and trypsin-resistant components as previously described (14). The radioactivity in the supernatant after trypsinization was standardized per milligram protein in the recovered cell pellet. Radioactivity associated with the cell pellet was termed trypsin resistant.

Analytical assays. Protein in the cell pellet was measured with the protein-binding dye reagent (Bio-Rad Laboratories, Richmond, CA) by the use of bovine gamma globulin as standard (20) or with the Folin phenol reagent (21) by use of bovine serum albumin as standard; results for the two assays in direct comparison were similar. Surfactantassociated proteins were analyzed by the fluorescamine method (22). Phospholipid phosphorus was measured by the use of 1,2,4-aminonaphthol sulfonic acid (23) with the assumption that phosphorus represented $4 \%$ of lipid weight.

Silica gel thin-layer chromatography of phospholipids was done by the method of Mitnick et al. (24) with co-chromatography of authentic standards (Avanti Polar Lipids, Inc., Birmingham, AL). Phospholipids were identified by brief exposure to iodine vapors and spots were scraped and analyzed for phosphorous.

Phospholipase activity was measured by the appearance of radioactivity in lyso PC during incubation with $\left[{ }^{3} \mathrm{H}\right] \mathrm{DPPC} /$ cholesterol vesicles suspended in modified Eagle's medium (pH 7.4). Reaction volume was $0.5 \mathrm{ml}$ and DPPC was present at a final concentration of $350 \mu \mathrm{M}$. Lyso PC was separated by thin-layer chromatography (24).

SDS-polyacrylamide gel electrophoresis was done by the method of Weber, Pringle, and Osborn by the use of $10 \%$ acrylamide gel and stained with Coomassie Blue (25).

Radioactivity was measured by scintillation counting with quench corrections based on internal standards.

Uptake of erythrosin B was evaluated with an inverted microscope to determine dye exclusion by the cells attached to plastic culture flasks (16).
Data were analyzed for statistical significance by the $t$ test for independent samples (26). The linear regression of uptake of phospholipids vs. time was calculated by least mean square analysis and analyzed for statistical significance (control vs. experimental) by the $Z$ test on the correlation coefficients (26). The level of statistical significance was taken as $P<0.05$.

\section{Results}

The method of surfactant isolation gave $\sim 90 \mu \mathrm{g}$ of total protein per rat ( $\sim 2 \mathrm{~g}$ lung wet $w t)$ (Table I). Extraction of the surfactant with ethanol/ether yielded $17 \%$ of the total surfactantassociated proteins and most of the recovered phospholipid (Table I). As previously reported (11), these ethanol/ether soluble proteins reacted poorly with the Lowry reagent (21) but were detected with fluorescamine (22).

When the ethanol/ether soluble fraction was analyzed by silicic acid chromatography, the proteins eluted into one major peak which was in the $4: 1$ chloroform/methanol solvent pool (Fig. 1). The several protein-containing fractions in this solvent pool were combined and used for further studies. This protein, which accounted for $\sim 85 \%$ of the protein recovered from the silicic and column, was called apoprotein Et (Apo Et) because it is ethanol/ether soluble. With some surfactant preparations, additional minor peaks of protein were detected in the 20:1 and 3:2 solvent pools as previously reported in abstract form (27). These pools together generally accounted for $<15 \%$ of total ethanol/ether soluble protein and were not evaluated further. Total recovery of applied protein from the silicic acid column exceeded $90 \%$. Recovery of protein from the silicic acid column was not significantly different in one experiment in which $0.25 \mathrm{mM}$ phenylmethylsulfonyl fluoride was added to the solution used for lung lavage to inhibit possible proteolysis.

Although a small amount of phospholipid was consistently associated with Apo Et (phospholipid-to-protein ratio, 0.3), $>80 \%$ of phospholipids were eluted from the silicic acid column in the 1:4 chloroform/methanol pool. Thus, the phospholipid peak was clearly separated from the major protein peak (Fig. 1). Apo Et appeared to be monophoretic by SDSpolyacrylamide gel electrophoresis (Fig. 2) and had a molecular weight $\sim 10,500$.

Table I. Recovery of Protein and Total Phospholipid in the Ethanol/Ether Soluble and Insoluble Fractions of Rat Lung Surfactant

\begin{tabular}{lcc}
\hline & Soluble fraction & Insoluble fraction \\
\hline Protein ( $\mu$ g/rat lung) & $15.0 \pm 1.6$ & $74.0 \pm 4.4$ \\
Phospholipid ( $\mu$ g/rat lung) & $212 \pm 31.8$ & $7.0 \pm 1.0$ \\
Phospholipid/protein & $13.8 \pm 0.85$ & $0.09 \pm 0.01$ \\
\hline
\end{tabular}

Results are mean \pm SE for six determinations. Rats weighted 200$250 \mathrm{~g}$. 


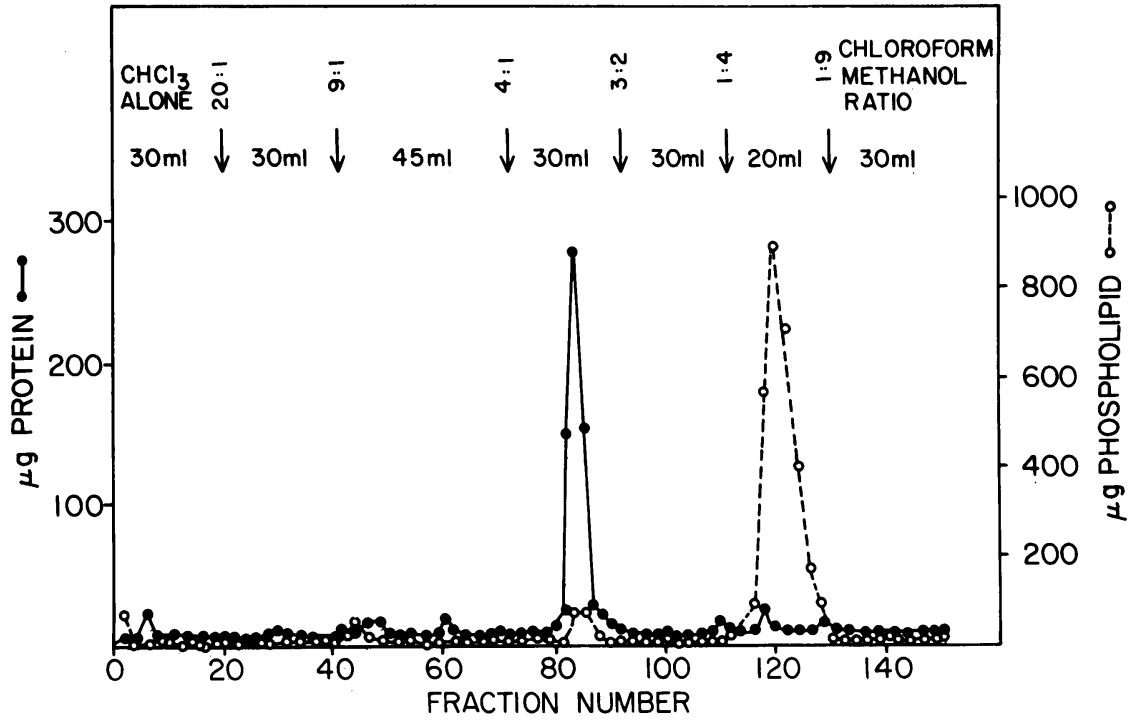

Figure 1. Silicic acid chromatography of rat lung surfactant ethanol/ether soluble proteins. Protein was measured with fluorescamine (22) and phospholipid phosphorous was determined by Bartlett's method (23), with inorganic phosphorous assumed to be $4 \%$ of the total phospholipid weight.
Control cells accumulated liposomal PC from the medium (Table II) as previously described (14). In the presence of Apo Et, uptake of PC was significantly stimulated by $61 \%$ (Table II). On the other hand, the presence of the ethanol/ether insoluble apoprotein depressed uptake of liposomal PC. In the presence of both apoprotein fractions, uptake was stimulated significantly over that with the ethanol/ether insoluble apoproteins alone. The treatment of Apo Et for $15 \mathrm{~min}$ at $100^{\circ} \mathrm{C}$ (one experiment) resulted in a complete loss of the ability to stimulate PC uptake by granular pneumocytes (data not shown).
These studies (Table II) were carried out with apoprotein incorporated into liposomes. Parallel incubations with Apo Et $(0.83 \mu \mathrm{g} / \mathrm{ml})$ added to the cell culture medium $5 \mathrm{~min}$ before the addition of liposomes showed stimulation of uptake by $55 \pm 15 \%(n=3 ; P<0.02)$ compared with control (no added protein). The addition of bovine serum albumin $(5 \mu \mathrm{g} / \mathrm{ml})$ instead of Apo Et had no effect on liposome uptake.

Although the presence of Apo Et significantly stimulated uptake, it was not clear whether this activity resided with the native protein or resulted from alteration by silicic acid treat-
A

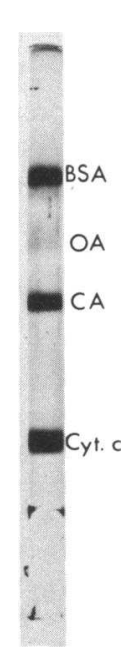

B

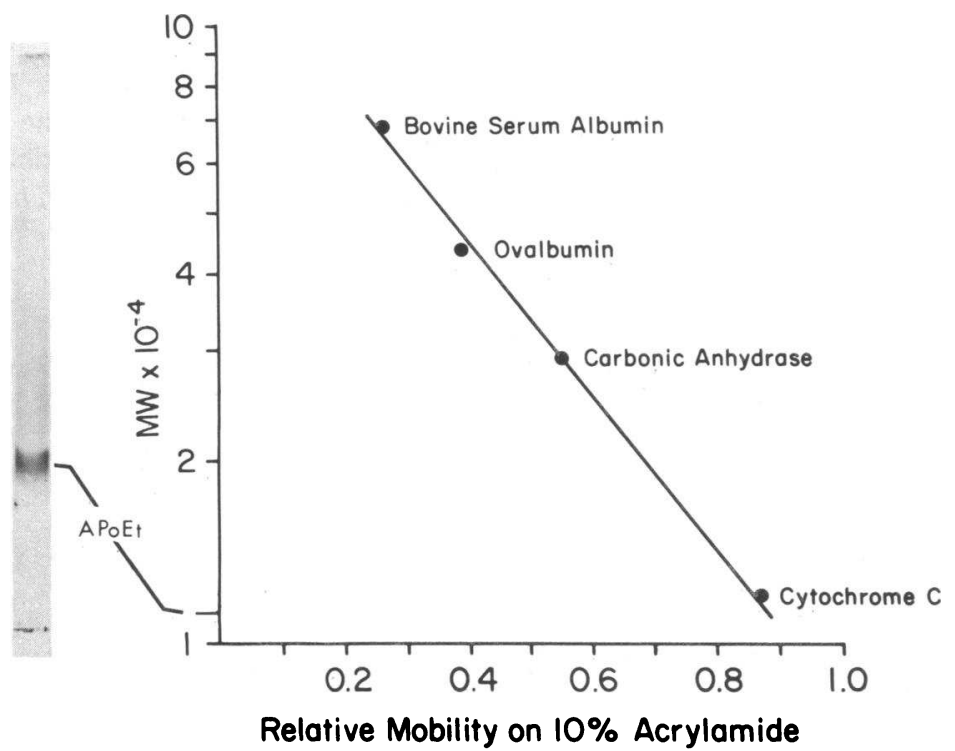

Figure 2. (A) SDS-10\% polyacrylamide gel electrophoresis of the ethanol/ether soluble protein (Apo Et) stained with Coomassie Blue. Protein standards were bovine serum albumin (BSA), ovalbumin (OA), carbonic anhydrase (CA), and cytochrome C (Cyt. C). (B) The standard curve for relative mobility as a function of molecular weight. The migration of Apo Et is indicated on the ordinate. 
Table II. Effect of Apo Et and Ethanol/Ether Insoluble Proteins on Uptake of Liposomal PC by Granular Pneumocytes

\begin{tabular}{ll}
\hline & Uptake \\
\hline & nmol PC/mg cell protein \\
Control & $0.95 \pm 0.09(12)$ \\
+Apo Et & $1.53 \pm 0.12(12)^{*}$ \\
+Ethanol/ether insoluble proteins & $0.69 \pm 0.11(3)$ \\
+Apo Et + Ethanol/ether insoluble proteins & $1.10 \pm 0.01(3) \ddagger$ \\
\hline
\end{tabular}

Values are mean $\pm \mathrm{SE}$ for $(n)$ experiments. Cells were incubated for 2 h with $21 \mu \mathrm{m} \mathrm{PC}, 4.2 \mu \mathrm{g} / \mathrm{ml} \mathrm{Apo} \mathrm{Et,} \mathrm{and/or} 21 \mu \mathrm{g} / \mathrm{ml}$ ethanol-ether insoluble proteins.

$* P<0.01$ vs. control.

$\ddagger P<0.01$ vs. ethanol/ether insoluble protein.

ment during isolation. Therefore, we evaluated a possible effect of the original ethanol/ether extract in comparison with the effect of Apo Et isolated by silicic acid treatment. For these experiments, the phospholipid concentration of the control liposome mixture was adjusted to approximate the value measured for phospholipids in the ethanol/ether extract. The presence of Apo Et stimulated uptake of liposomal PC by $28 \%$ compared with control (no added protein) (Table III). This relatively lower rate of stimulation compared with data in Table II can be ascribed to the lower concentration of Apo Et used in these experiments. Uptake of liposomal PC in the presence of the ethanol/ether extract containing the native protein was similar to that observed with the addition of Apo Et (Table III). These experiments indicate that the effect of Apo Et on stimulation of liposomal phospholipid uptake was not due to the treatment with silicic acid during isolation.

The effect of Apo Et on liposomal PC uptake was evaluated over a broader range of time points up to $3 \mathrm{~h}$ of incubation

Table III. Comparison of Apo Et and the Ethanol/Ether Extract of Lung Surfactant on Uptake of Liposomal PC by Granular Pneumocytes

\begin{tabular}{ll}
\hline & Uptake \\
\hline & $n m o l P C / m g$ cell protein \\
Control & $0.79 \pm 0.03$ \\
Control + Apo Et & $1.01 \pm 0.03^{*}$ \\
Ethanol/ether extract & $1.03 \pm 0.06^{*}$
\end{tabular}

Values are mean $\pm S E$ for three experiments under each condition. Incubation was for $2 \mathrm{~h}$. For control experiments, liposomes contained $13 \mu \mathrm{M}$ PC. Apo Et was added at $1 \mu \mathrm{g} / \mathrm{ml}$. During incubation with the ethanol/ether extract of lung surfactant, the incubation medium contained $8.6 \mu \mathrm{M} \mathrm{PC}$ and $0.8 \mu \mathrm{g} / \mathrm{ml}$ of protein (estimated Apo Et concentration, $0.7 \mu \mathrm{g} / \mathrm{ml}$ ).

$* P<0.01$ vs. control.
(Fig. 3). Uptake was $0.14 \mathrm{nmol} / \mathrm{h}$ per $\mathrm{mg}$ cell protein ( $r$ $=0.71$ ) under control conditions and increased approximately fivefold to $0.70 \mathrm{nmol} / \mathrm{h}$ per $\mathrm{mg}$ cell protein $(r=0.93)$ in the presence of Apo Et $(P<0.05)$.

The effect of Apo Et on liposomal phospholipid uptake by primary cultures of Type II cells was concentration dependent (Table IV). Liposome uptake by Type II cells at $2 \mathrm{~h}$ increased progressively with increasing Apo Et concentration. If the molecular weight of Apo Et were assumed to be $10,500 \mathrm{D}$, a concentration of Apo Et of $4.2 \mu \mathrm{g} / \mathrm{ml}$ would be $\sim 0.4 \mathrm{nM}$. Since the phospholipid concentration in this experiment was $21 \mu \mathrm{M}$, the phospholipid-to-protein molar ratio for nearmaximal stimulation of uptake was $\sim 50$.

Our previous studies have indicated a time-dependent increase in the fraction of liposomal PC radioactivity associated with cells which is resistant to removal by mild proteolytic treatment with trypsin (14). We have speculated that this trypsin insensitive radioactivity represents internalized phospholipid since it correlated well with internalization of a marker for the liposomal aqueous compartment (14). In order to determine the effect of Apo Et on the proportion of phospholipid that was trypsin insensitive, we evaluated the trypsin resistance of cell-associated phospholipid in the presence of increasing concentrations of Apo Et (Table IV). In the absence of added protein, $62 \%$ of PC was trypsin resistant after $\mathbf{2} \mathrm{h}$ of incubation. With increasing concentrations of Apo Et, the trypsin-resistant phospholipid progressively increased, suggesting internalization of the Apo Et-augmented cell-associated radioactivity.

The effect of Apo Et on uptake of radiolabeled lipid could have been due to phospholipase activity of this protein, resulting in release of either radiolabeled fatty acids or lyso PC from PC. We investigated this possibility by measuring the phospholipase activity of Apo Et. Control incubations did not contain any protein. Radioactivity recovered in lyso PC in control incubations was $0.3 \%$ of the total radioactivity at zero time and did not increase during $2 \mathrm{~h}$ of incubation. The presence of Apo Et $(1.6$ and $3.2 \mu \mathrm{g} / \mathrm{ml})$ did not increase the radioactivity in lyso PC during an incubation of up to $2 \mathrm{~h}$. Therefore, the effect of Apo Et on PC uptake by Type II cells was not due to phospholipase activity of this protein.

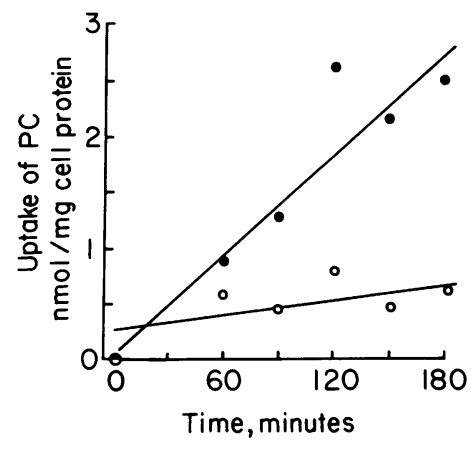

Figure 3. Uptake of $\mathrm{PC}$ as a function of time of incubation by cells incubated in the presence $(\bullet)$ or absence (o) (control) of Apo Et $(0.83 \mu \mathrm{g} / \mathrm{ml})$. PC concentration was $25 \mu \mathrm{M}$. The initial cell associated value was subtracted from all values at subsequent time points. Lines were drawn by least mean square analysis (26). 
Table IV. Effect of Various Concentrations of Apo Et on Uptake of Liposomal PC by Granular Pneumocytes

\begin{tabular}{lllll}
\hline Apo Et & Total uptake & $\begin{array}{l}\% \\
\text { Increase }\end{array}$ & Trypsin resistant & $\begin{array}{l}\% \\
\text { Increase }\end{array}$ \\
\hline$\mu g / m l$ & $n m o l ~ P C / m g$ cell protein & & $n m o l ~ P C / m g$ cell protein \\
0 & $1.01 \pm 0.03(6)$ & - & $0.63 \pm 0.05$ & - \\
0.42 & $1.21 \pm 0.01(3)$ & 20 & $0.76 \pm 0.04$ & 21 \\
0.84 & $1.35 \pm 0.06(3)$ & 34 & $0.87 \pm 0.04$ & 39 \\
4.2 & $1.62 \pm 0.15(7)$ & 61 & $1.21 \pm 0.11$ & 93
\end{tabular}

Results are mean \pm SE for $(n)$ experiments. Cells were incubated for $2 \mathrm{~h}$ with liposomes prepared with various concentrations of Apo Et. The PC concentration during incubation was $21 \mu \mathrm{M}$ for all conditions.

We further evaluated if the effect of Apo Et was due to solubilization of lipid vesicles. DPPC/cholesterol (1:1) vesicles with encapsulated carboxyfluorescein were monitored for the possible release of fluorescent material into the incubation medium (28) in the presence of Apo Et or the ethanol/ether insoluble protein during $30 \mathrm{~min}$ of incubation at $37^{\circ} \mathrm{C}$. The results were calculated as the percentage of total fluorescence (taken after treatment of vesicles with Triton X-100) released during incubation. The increase in fluorescence in control incubation (no added protein) was subtracted. Whereas the ethanol/ether insoluble protein increased carboxyfluorescein release by $2.5 \%$, Apo Et increased release by only $0.3 \%$. Since the ethanol/ether insoluble protein did not stimulate uptake of liposomal PC, solubilization of lipid vesicles does not appear to be the underlying mechanism of stimulation of uptake by Apo Et.

Another possible explanation for the effect of Apo Et on liposome uptake by cells was that the protein altered Type II cell viability and thereby allowed the penetration of liposomes through damaged cell membranes. To evaluate this possibility, exclusion of dye (i.e., erythrosin B) was used as an index of possible cell damage (29). Erythrosin B exclusion was high at the start of incubation and showed no decrease during $2.5 \mathrm{~h}$ of incubation in the presence or absence of Apo Et (Table V).

Table V. Effect of Apo Et on Erythrosin B Exclusion by Granular Pneumocytes

\begin{tabular}{lll}
\hline Time of incubation & Apo Et added & Dye exclusion \\
\hline $\min$ & $\mu g / m l$ & $\%^{*}$ \\
0 & 0 & 87 \\
150 & 0 & 87 \\
150 & 1 & 91 \\
150 & 5 & 92
\end{tabular}

More than 600 cells were evaluated for each group. Cells were incubated for indicated times in presence of liposomes at a concentration of $25 \mu \mathrm{M}$ PC.

* Percentage of cells that were unstained 5-10 min after addition of erythrosin B.
This experiment does not take into account cells that might become detached from the plastic during incubation, but these cells would also be excluded from the analysis of PC uptake. We conclude that augmentation of liposome uptake by the presence of Apo Et was not due to cell damage.

Modified granular pneumocytes ( $7 \mathrm{~d}$ in culture) also accumulated liposomal PC, but the total uptake in $2 \mathrm{~h}$ per milligram protein was decreased $37 \%$ compared with control granular pneumocytes ( $1 \mathrm{~d}$ in culture) (Table VI). In the presence of Apo Et, total uptake of PC by modified granular pneumocytes was increased by $30 \%$ and trypsin resistant uptake was increased by $3 \%$. These relatively small effects of Apo Et were not statistically significant.

Alveolar macrophages have also been shown to accumulate liposomal phospholipids (14). Although they accounted for $<10 \%$ of total cells in the granular pneumocyte primary cultures, macrophages could have contributed to the stimulated liposomal phospholipid uptake. To assess their contribution, the effect of Apo Et on uptake of liposomal phospholipids by alveolar macrophages in primary culture was evaluated. Apo Et stimulated uptake of liposomes by alveolar macrophages by $72 \%$ (Table VI). However, the total uptake of phospholipid by alveolar macrophages was only about one-half of that observed with Type II cells. Consequently, alveolar macrophage contamination could not have accounted for the observed stimulation of liposome uptake by Apo Et in the granular pneumocyte preparation. The ethanol/ether insoluble proteins did not significantly affect the liposome uptake by alveolar macrophages (Table VI).

\section{Discussion}

Data presented here confirm the presence of proteins in the ethanol/ether extracted material from rat lung surfactant. We found that $17 \%$ of the total rat lung surfactant protein was soluble in ethanol/ether. This is similar to what has been

Table VI. Effect of Apo Et on Liposomal PC Uptake by Modified Granular Pneumocytes and Alveolar Macrophages

\begin{tabular}{|c|c|c|c|}
\hline & \multicolumn{3}{|c|}{ Uptake of PC (nmol/mg cell protein) } \\
\hline & \multicolumn{2}{|c|}{ Modified granular pneumocytes* } & \multirow{2}{*}{$\frac{\text { Alveolar macrophages }}{\text { Total uptake }}$} \\
\hline & Total uptake & Trypsin resistant & \\
\hline Control & $0.60 \pm 0.17$ & $0.29 \pm 0.09$ & $0.32 \pm 0.05$ \\
\hline $\begin{array}{l}\text { +Apo Et } \\
+ \text { Ethanol/ether }\end{array}$ & $0.78 \pm 0.23$ & $0.30 \pm 0.11$ & $0.55 \pm 0.07 \ddagger$ \\
\hline insoluble proteins & - & - & $0.41 \pm 0.04$ \\
\hline
\end{tabular}

Results are mean \pm SE for four experiments with modified granular pneumocytes and three experiments with alveolar macrophages. Cells were incubated for $2 \mathrm{~h}$ with $21 \mu \mathrm{M} \mathrm{PC}$ in the presence or absence of $4.2 \mu \mathrm{g} / \mathrm{ml}$ of Apo Et or $21 \mu \mathrm{g} / \mathrm{ml}$ of ethanol/ether insoluble proteins.

* Granular pneumocytes maintained for 1 wk in primary culture.

$\ddagger P<0.01$ vs. control. 
described with porcine lung surfactant (11), although an earlier study of dog lung had failed to find significant protein in this fraction (8). This discrepancy has been ascribed to the poor reactivity of this protein with the Lowry reagent (11), although species differences cannot be excluded. We have confirmed this fraction to be protein by its reactions with fluorescamine and Coomassie Blue, its migration on polyacrylamide gels, and its loss of activity upon heating. Furthermore, our preliminary studies demonstrate the presence of amino acids after acid digestion. Ethanol/ether soluble protein also has been isolated from lamellar bodies of porcine lung (11). The protein from this latter source was fractionated into four major peaks by silicic acid chromatography. Using a similar scheme with ethanol/ether soluble protein from rat lung surfactant, we recovered $>85 \%$ of protein as a single peak. This single peak could not be further resolved by the use of $1: 1$ and $1: 2$ chloroform/methanol ratios in the elution profile. It should be noted that the previous study did not report fractionation of ethanol/ether soluble proteins for the lung lavage material (11). Proteins from rat lung surfactant were further distinguished from the hydrophobic proteins from porcine lung lamellar bodies (11) by our finding that we could remove most of the phospholipids from Apo Et with silicic acid chromatography, possibly because we used more silicic acid per milligram phospholipid or used a more prolonged time for organic solvent extraction. However, some phospholipid remained associated with the major protein peak, which may account for its lipid solubility.

Previous work from our laboratory has shown that granular pneumocytes internalize liposomes at a rate that varies with phospholipid concentration and liposome composition and is inhibited by low temperature, fluoride, and 2-deoxyglucose (14). The process of liposomal phospholipid uptake appears to involve surface binding followed by internalization. The present results show that the ethanol/ether soluble protein fraction (Apo Et) of surfactant significantly augments the time-dependent uptake of liposomal PC by isolated granular pneumocytes. Since the augmented uptake is predominantly trypsin resistant, it apparently represents phospholipid that has been internalized.

The mechanism for augmentation of liposome uptake by Apo Et is not yet fully elucidated. It did not, however, appear to be related to damage to cell membranes, phospholipase activity, or solubilization of liposomes. Stimulation of uptake of PC by Apo Et may be mediated through increased binding of lipids to the cell membrane, since this protein increased the absolute amount of radioactivity that was releasable with trypsin treatment in addition to increasing trypsin-resistant uptake (Table IV). However, further studies will be required to delineate the precise mechanism through which membrane binding of PC and its uptake is augmented by the presence of Apo Et.

In contrast to granular pneumocytes after $24 \mathrm{~h}$ in culture, those maintained for $7 \mathrm{~d}$ did not show stimulation of trypsinresistant PC uptake by Apo Et. The reason for the failure to respond to Apo Et cannot be determined from these studies.
A loss of the appropriate receptors is one possibility and may be a manifestation of the apparent dedifferentiation of these cells (18). Nevertheless, these results demonstrate that stimulation of phospholipid uptake by Apo Et is not a generalized property of cells in culture.

Synthesis and secretion of surfactant lipids is known to occur at a rapid rate with a turnover time for DPPC of 10.7 $h$ in the rabbit (30) and a biological half-life in the rat of $\sim 4$ $h$ (10). The process of clearance of the secreted phospholipids is less well understood. Recent studies have indicated that the phospholipids are cleared predominantly through the alveolar epithelium, with a smaller but undetermined fraction cleared by alveolar macrophages. Geiger, Gallagher, and Hedley-Whyte have shown the ability of the lung epithelial lining cells to remove and concentrate exogenous phospholipids instilled in the airspaces (31). Since Apo Et is normally present in the alveolar space, stimulation of uptake by this protein would provide a physiologic mechanism for augmenting the clearance of surfactant phospholipids by granular pneumocytes as well as alveolar macrophages. Stimulation of uptake appears to be specific for this surfactant-associated protein, since neither the ethanol/ether insoluble surfactant proteins nor bovine serum albumin stimulated uptake. Consequently, the studies suggest that the ethanol/ether soluble protein fraction of lung surfactant may have a role in the clearance of this material from the alveolar space.

\section{Acknowledgments}

We thank Jerry Zuckerman for assistance with studies of the interaction of apoproteins with lipid vesicles.

This work was supported in part by grant HL 19737 from the National Institutes of Health. Dr. Claypool was supported by an Individual National Research Service Award HL-06456.

\section{References}

1. Goerke, J. 1974. Lung surfactant. Biochim. Biophys. Acta. 344:241-261.

2. King, R. J. 1974. The surfactant system of the lung. Fed. Proc. 33:2238-2247.

3. Gluck, L. 1971. Biochemical development of the lung: clinical aspects of surfactant development, RDS, and the intrauterine assessment of lung maturity. Clin. Obstet. Gynecol 14:710-727.

4. Farrell, P. M., and M. E. Avery. 1975. Hyaline membrane disease. Am. Rev. Respir. Dis. 111:657-688.

5. Comroe, J. H. 1977. Premature science and immature lungs. Am. Rev. Respir. Dis. 116:127-135, 311-323, and 497-518.

6. King, R. J., H. Martin, D. Mitts, and F. M. Holstrom. 1977. Metabolism of the apoproteins in pulmonary surfactant. J. Appl. Physiol. 42:483-491.

7. Williams, M. C., and B. J. Benson. 1981. Immunocytochemical localization and identification of the major surfactant protein in adult rat lung. J. Histochem. Cytochem. 29:291-305.

8. King, R. J., D. J. Klass, E. G. Gikas, and J. A. Clements. 1973. Isolation of apoproteins from surface active material. Am. J. Physiol. 224:788-795.

9. King, R. J., E. G. Gikas, J. Ruch, and J. A. Clements. 1974. 
The radioimmunoassay of pulmonary surface active material in sheep lung. Am. Rev. Respir. Dis. 110:273-281.

10. King, R. J., and H. Martin. 1980. Intracellular metabolism of the apoproteins of pulmonary surfactant in rat lung. J. Appl. Physiol. 48:812-820

11. Phizackerly, P. J. R., M. H. Town, and G. E. Newman. 1979. Hydrophobic proteins of lamellated osmiophillic bodies isolated from pig lung. Biochem. J. 183:731-736.

12. Hallman, M., B. L. Epstein, and L. Gluck. 1981. Analysis of labeling and clearance of lung surfactant phospholipids in rabbit. Evidence of bidirectional surfactant flux between lamellar bodies and alveolar lavage. J. Clin. Invest. 68:742-751.

13. Jacobs, H., A. Jobe, M. Ikegami, and D. Conaway. 1983. The significance of reutilization of surfactant phosphatidylcholine. J. Biol. Chem. 258:4156-4165.

14. Chander, A., W. D. Claypool, Jr., J. F. Strauss III, and A. B. Fisher. 1983. Uptake of liposomal phosphatidylcholine by granular pneumocytes in primary culture. Am. J. Physiol. 245(Cell Physiol. 14):C397-C404.

15. Katyal, S. L., L. W. Estes, and B. Lombardi. 1977. Method for the isolation of surfactant from homogenates and lavages of adult, newborn, and fetal rats. Lab. Invest. 36:585-592.

16. Fisher, A. B., L. Furia, and H. Berman. 1980. Metabolism of rat granular pneumocytes isolated in primary culture. J. Appl. Physiol. 49:743-750.

17. Kerr, J. S., J. Reicherter, and A. B. Fisher. 2-Deoxy-D-glucose uptake by rat granular pneumocytes in primary culture. Am. J. Physiol. 243:C14-19, 1982.

18. Diglio, C. A., and Y. Kikkawa. 1977. The type II epithelial cells of the lung, IV. Adaptation and behavior of isolated type II cells in culture. Lab. Invest. 37:622-631.

19. Hamilton, R. L., J. Goerke, L. S. S. Guo, M. C. Williams, and R. J. Havel. 1980. Unilamellar liposomes made with the French pressure cell: a simple preparative and semiquantitative technique. $J$. Lipid. Res. 21:981-992.
20. Bradford, M. M. 1976. A rapid and sensitive method for the quantitation of microgram quantities of protein utilizing the principle of protein-dye binding. Anal. Biochem. 72:248-254.

21. Lowry, O. H., N. J. Rosebrough, A. L. Farr, and R. J. Randall. 1951. Protein measurement with the Folin phenol reagent. J. Biol. Chem. 193:265-275.

22. Bohlen, P., S. Stein, W. Dairman, and S. Undenfriend. 1973. Fluorometric assay of proteins in the nanogram range. Arch. Biochem. Biophys. 155:213-220.

23. Bartlett, G. R. 1959. Phosphorus assay in column chromatography. J. Biol. Chem. 234:466-468.

24. Mitnick, M. A., B. DeMarco, and J. M. Gibbons. 1980. Amniotic fluid phosphatidylglycerol and phosphatidylinositol separated by stepwise-development thin-layer chromatography. Clin. Chem. 26:277-281.

25. Weber, K., J. R. Pringle, and M. Osborn. 1972. Measurement of molecular weights by electrophoresis on SDS-acrylamide gel. Methods Enzymol. 26:3-27.

26. Croxton, F. E. 1959. Elementary Statistics. Dover Publications, Inc., Mineola, New York. 226-230 and 312-316.

27. Claypool, W. D., Jr., A. Chander, and A. B. Fisher. 1981. Isolation of the hydrophobic proteins of rat lung surfactant. Fed. Proc. 40:408. (Abstr.)

28. Guo, L. S. S., R. L. Hamilton, J. Goerke, J. N. Weinstein, and R. J. Havel. 1980. Interaction of unilamellar liposomes with serum lipoproteins and apolipoproteins. J. Lipid Res. 21:993-1003.

29. Hanks, J. H., and J. H. Wallace. 1958. Determination of cell viability. Proc. Soc. Exp. Biol. Med. 98:188-192.

30. Baritussio, A., M. W. Magoon, J. Goerke, and J. A. Clements. 1981. Precursor-product relationship between rabbit Type II cell lamellar bodies and the alveolar surface active material. Surfactant turnover time. Biochim. Biophys. Acta. 666:382-393.

31. Geiger, K., M. L. Gallagher, and J. Hedley-Whyte. 1975. Cellular distribution and clearance of aerosolized dipalmitoyl leicithin. J. Appl. Physiol. 39:759-766. 